\title{
Assessing land-use changes in tourism area on the example of Čajetina municipality (Serbia)
}

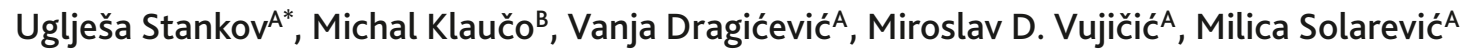 \\ Received: February 19, 2016 | Revised: April 23, 2016 | Accepted: June 3, 2016
}

DOI: 10.18421/GP20.02-07

\begin{abstract}
Tourism development can strongly affect purpose of land use at the destination and in surrounding areas. However, the effects of development in tourism destination cannot be easily visible and proven. Sometimes indicators of tourism development do not show its significant impact, but the structural changes are occurring and they affect land use. The aim of this paper is to employ methodology for assessing effects of development on land-use changes in tourism destination. Proposed methodology includes combination of the use of publically available geographical data, geographical information systems and landscape metrics. The applicability of this approach has been investigated in test region of Čajetina municipality (south-western part of the Republic of Serbia), where tourism industry has flourished in last decades. Time series of maps (2000 and 2006) have been obtained from CORINE land cover project. Landscape metrics for area, size and density have been calculated for the entire test region and for tourism destination at patch and class levels. The results showed significant effects of development on land use changes in investigated tourism area comparing to its surroundings.
\end{abstract}

Keywords: GIS, land use, landscape metrics, tourism, Čajetina municipality, Serbia.

\section{Introduction}

In order to understand the function and change of the landscape, it is a prerequisite to quantify the landscape structure (O’Neill, et al.,1988; Turner, Gardner, 1991; Turner, et al, 2001). In recent years, the development of geographic information system (GIS) makes temporal and spatial information easily accessible for broad use. Spatial analysis capability and presentation makes it a useful tool for studying landscape spatial structure and land use change analysis.

The relationship between tourism and landscape can be described as systematic. When changing elements or conditions change within the system, all subsystems and other elements are altered. A landscape for contemporary tourism has different meanings: it is a habitat and place to live; an area for production; a place for recreation; a place for experience, emotion and perception; and a place for culture and settlements. As with any human activity, tourism affects the social and natural environment (Bastian, Steinhardt, 2002). Tourism activities are often occurring in attractive and unique places that are sometimes more sensitive to change than other areas. Human impacts on landscapes caused by touristic activities should not change natural landscape elements, their function and processes, as well as environmental quality (Klaučo, et al., 2015). In other words, it is important to sustain diversity of landscapes as it can provide extra touristic income and support adequate land use (Sallay, et al., 2012; Stojanović, et al., 2011).

Tourism destinations do not exist in isolation. They are nested within larger surroundings. In other words,

\footnotetext{
A University of Novi Sad, Faculty of Sciences, Department of Geography, Tourism and Hotel Management, Trg Dositeja Obradovića 3, 21000 Novi Sad, Serbia; ugljesa.stankov@dgt.uns.ac.rs

B University of Matej Bel, Faculty of Sciences, Department of Geography, Geology and Landscape Ecology, Tajovského 40, 97401 Banská Bystrica, Slovakia

* Corresponding author: Uglješa Stankov, e-mail: ugljesa.stankov@dgt.uns.ac.rs
} 
each tourism destination has a context or regional settings (Dolinaj, et al., 2009). Tourism destinations are often open systems; tourist, traffic, energy, materials move into and out of the tourism zone. In this context, tourism development can alter traditional land use at the destination and in surrounding areas. However, the effects of development in the tourism region cannot be easily visible and proven. Sometimes indicators of tourism development do not show its significant impact, but the structural changes are occurring and they affect land use. Thus, the aim of this paper is to assess land-use changes in an area surrounding traditional tourist centre, to compare it to more larger administrative area, in this case, the municipality area. For the assessment this study employs GIS and quantitative indices of landscape patterns. The applicability of using this methodology has been investigated in test region of Čajetina municipality (south-western part of the Republic of Serbia), where tourism industry has flourished in last decades, mostly in one traditional tourist centre. Landscape metrics for area, size and density (CA, PLAND, NP, PD, MPA and PASD) have been calculated for the entire municipality and for defined tourism area at class level.

\section{Theoretical background}

Applications of landscape metrics to evaluate the effects of development in tourism destination on land use pattern changes have not been frequently used. On the other hand, the characterization of landscape mosaics and patterns has a long tradition in ecological studies (Wickham, Norton 1994; Kareiva, Wennergren 1995). Land use change has aroused increasing attention of scientists worldwide. Various models of land use change have been developed for better understanding of relationships and interactions between human and natural phenomena (Mineto, Polyzos, 2009; Feranec, et al., 2010).

Landscape metrics are used to conduct analysis of landscape patterns. A large number of indices to characterize the landscape have been developed, some of which describe the proportion of the landscape with a particular land cover class, the size, number, and perimeter of each land cover patch, and the complexity of the shape of the patch (McGarigal, et al., 2002). These indices of landscape patterns have been used widely in ecology for decades (Seto, Fragkias, 2005). Because tourism often occurs in environmentally fragile areas with high landscape quality, its impact on the environment is significant in ecological, visual and socio-cultural terms (Atik, 2009). Within this context, landscape indices can be applied in analyzing the effects of human impacts in tourism regions (Klauco, et al, 2012; Marković, et al., 2014).
Land use pattern analysis implies the use of categorical map patterns as they represent data system property as a mosaic of discrete patches. Patches form the basis (or building blocks) for categorical maps. While individual patches possess relatively few fundamental spatial characteristics (e.g., size, perimeter, and shape), collections of patches may have a variety of aggregate properties, depending on whether the aggregation is over a single class (patch type) or multiple classes, and whether the aggregation is within a specified sub region of a landscape or across the entire landscape. Commonly, landscape metrics may be defined at three levels: patch-level metrics, class-level metrics and landscape-level metrics (McGarigal, Marks, 1995; Gustafson, 1998). This study aims to focus research on class-level metrics. Class-level metrics are integrated over all the patches of a given type (class).

The common usage of the term "landscape metrics" refers exclusively to indices developed for categorical map patterns. Landscape metrics are algorithms that quantify specific spatial characteristics of patches, classes of patches, or entire landscape mosaics. These metrics fall into two general categories: those that quantify the composition of the map without reference to spatial attributes, and those that quantify the spatial configuration of the map, requiring spatial information for their calculation (McGarigal, Marks 1995; Gustafson, 1998).

\section{Materials and methods}

This research concentrates efforts on interpretation of landscape metrics obtained from map recourses. The method of the study comprises three main steps as following the diagram in Figure 1. First phase includes basic GIS activities, such as, data acquisition, managing, basic analyzing and displaying of georeferenced data (Jovanović, Njeguš, 2008; Jovanovic, Njegus, 2010). The determination of land use data with high geometric and thematic accuracy is generally limited by the availability of adequate remote sensing data, in terms of spatial and temporal resolution, and digital image analysis techniques (Herold, 2002). This can be an expensive and cost demanding step in the research, especially for tourism officials of smaller administrative units with limited resources. However, thanks to European Environment Agency's (EEA) data centre for land use European countries have the access to data for understanding the relationship between land use and environmental impacts. Information is provided at different scales combining European coverage with global and in situ survey data. In this research for database creation we used raster data obtained from EEA. Data are managed and analyzed using commercial ESRI's ArcGIS software. However, 
I phase-GIS: data acquisition, managing, basic analyzing and displaying

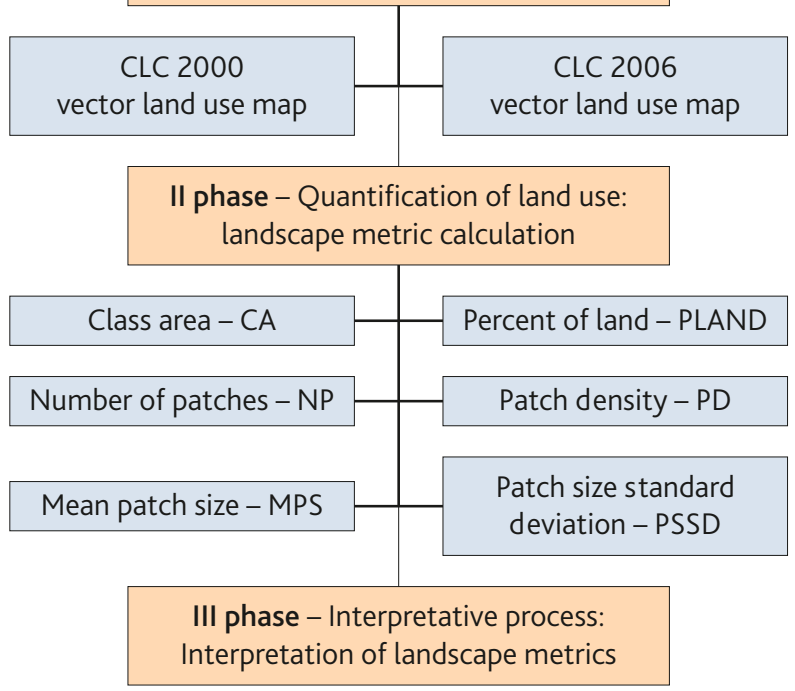

Figure 1. Flow diagram indicating main method phases

there are numerous open source software solutions having similar analysing capabilities.

Quantification of landscape structure is a key element for studying landscape changes (Klauco, et al, 2012). In second phase, a freeware spatial analysis program Fragstat was applied with purpose to calculate indices of the landscape structure using study maps. Landscape metrics (CA, PLAND, NP, PD, MPS and PSSD) have been calculated for the entire study region (municipality) and for tourism destination at class level. These indices were then used to interpret and analyze the landscape changes in the study area. The interpretation of landscape metrics was the third and final phase of the research.

\section{Study area - Čajetina municipality}

Čajetina municipality lies in the south-western part of the Republic of Serbia. Favourable geographical location of Čajetina municipality comes from its position on the main roads to Montenegro (the Adriatic Sea) and the Republic of Bosnia and Herzegovina. The City of Čajetina represents the seat of the municipality. The municipality covers the area of $647 \mathrm{~km} 2$. In 2010, Čajetina municipality had 15.080 inhabitants (Statistical Office of the Republic of Serbia, 2011).

The most developed activities in the area are agriculture, food processing industry and tourism. The agricultural area covers $57,9 \%$ of the municipality territory and live-stock breeding is the most important agricultural branch of this municipality (Statistical Office of the Republic of Serbia, 2011).

Zlatibor Mountain stretches across Bajina Bašta, Kosjerić, Užice, Požega, Čajetina, Arilje, Priboj, Nova Varoš, Prijepolje and Sjenica Municipalities representing the most prominent tourist resort in Serbia with the tourist tradition more than 110 years long. The mountain has exquisite natural and anthropogenic values (Jovićić, et al., 2013). Zlatibor Mt. is wavy plateau and belongs to the Dinaric Mountains. The average elevation is about $1000 \mathrm{~m}$. The highest peak is Tornik (1496 m). Nearly all area is covered with serpentine soil. In Stublo and Semegnjevo younger deposits of limestone are present, and south-eastern parts of Zlatibor Mt. abound in large quantities Triassic limestone. There is plenty of underground streams and caves. The average annual temperature in Zlatibor Mt. is around $7,5^{\circ} \mathrm{C}$. Zlatibor Mt. has a large number of sunny days (200 days annually), optimal air humidity and minimal temperature fluctuations so that it is famous both as air spa and sanatorium. Zlatibor Mt. is tilted toward the north and northwest and the rivers flow in that direction. The largest ecosystem where grows about 120 species of grasses (many of which have medicinal properties) consists of pastures, i.e. meadows. Up to $600 \mathrm{~m}$ deciduous species are dominant (beech, oak, birch, linden, ash). Over $600 \mathrm{~m}$ softwood dominates (white and black pine, fir, spruce) (Đenić, 1970; Ršumović, et al, 1991). The mountain is good for skiing and other sport and recreation activities, family stays, congress tourism, medical tourism, etc. (Regional Chamber of Commerce Užice, 2012).

Since the end of 19th century there was almost constant tourism development on the mountain. However, in the last 20 years there is a negative trend of tourist exploitation that strives to gain quick profit by extensively exploiting natural and anthropogenic values (Jovičić, et al., 2013). In Čajetina Municipality during investigated period of this study (2000-2006) the average number

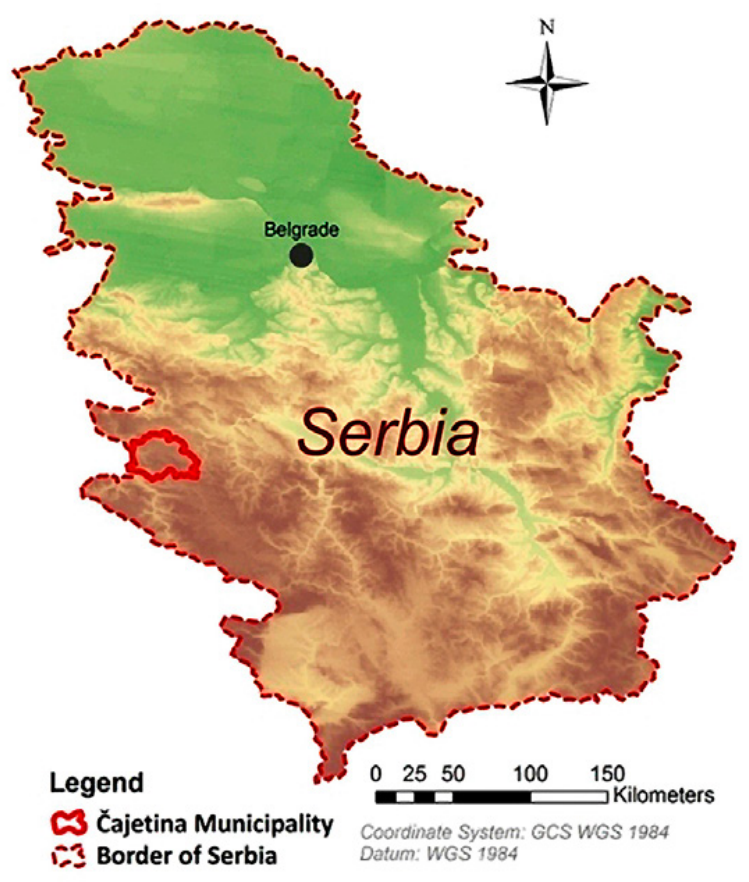

Figure 2. The location of Čajetina municipality in Serbia 
of officially registered tourist arrivals was about 83.000 yearly. Over $90 \%$ were domestic tourist. The average stay was 5 days. In the following period, starting from 2007 the total number of tourist arrivals significantly increased. In the period from 2007 to 2014 average number of tourist arrivals was around 111.000 yearly, with almost constant increase of foreign visitors (around 20\% in 2014). However, in that period average stay fell to 4 days (Statistical Office of the Republic of Serbia, 2001-2015).

Urban chaos and illegal buildings diminished the touristic attractiveness of Zlatibor Mt. (Dragović, et al., 2009). In the whole Zlatibor County, Čajetina has the lowest population density only people 24 per square $\mathrm{km}$. The average population density in the county is 44 people per square $\mathrm{km}$. However, the number of completed dwellings in Čajetina municipality shows different picture. In the reported period (2000-2006) the number of completed dwellings was the highest for 4 years, between 2000 and 2003. The trend continues from 2009 to 2014.

\section{Materials and data acquisition}

Corine Land Cover is the product of EEA and its member countries in the European environment information and observation network (Eionet). It is based on the results of IMAGE20oo, a satellite imaging programme undertaken jointly by the Joint Research Centre of the European Commission and the EEA. Corine Land Cover 2000 (CLC20oo) is based on the photo-interpretation of satellite images by the national teams of the participating countries. The resulting national land cover inventories are further integrated into a seamless land cover map of Europe (Klauco, et al., 2012).

CLC20oo has been made in scale of 1:100 ooo, with minimal mapping area of 25 ha and minimum width of linear elements of $100 \mathrm{~m}$. The mapping represents a trade-off between production costs and level of details of land cover information (Heymann, et al., 1994).

The classification of land use patches in this study was based on CLC20oo. The standard CLC nomenclature includes 44 land cover classes, grouped in a three-level hierarchy. The five main (level-one) categories are: 1) artificial surfaces, 2) agricultural areas, 3) forests and semi-natural areas, 4) wetlands, and 5) water bodies (Heymann, et al., 1994).

Based on various sources, such as the Business (master) plan of the tourist destination of ZlatiborZlatar (2007), The Spatial Plan of Čajetina (2010), online maps and commercial travel maps authors deline-
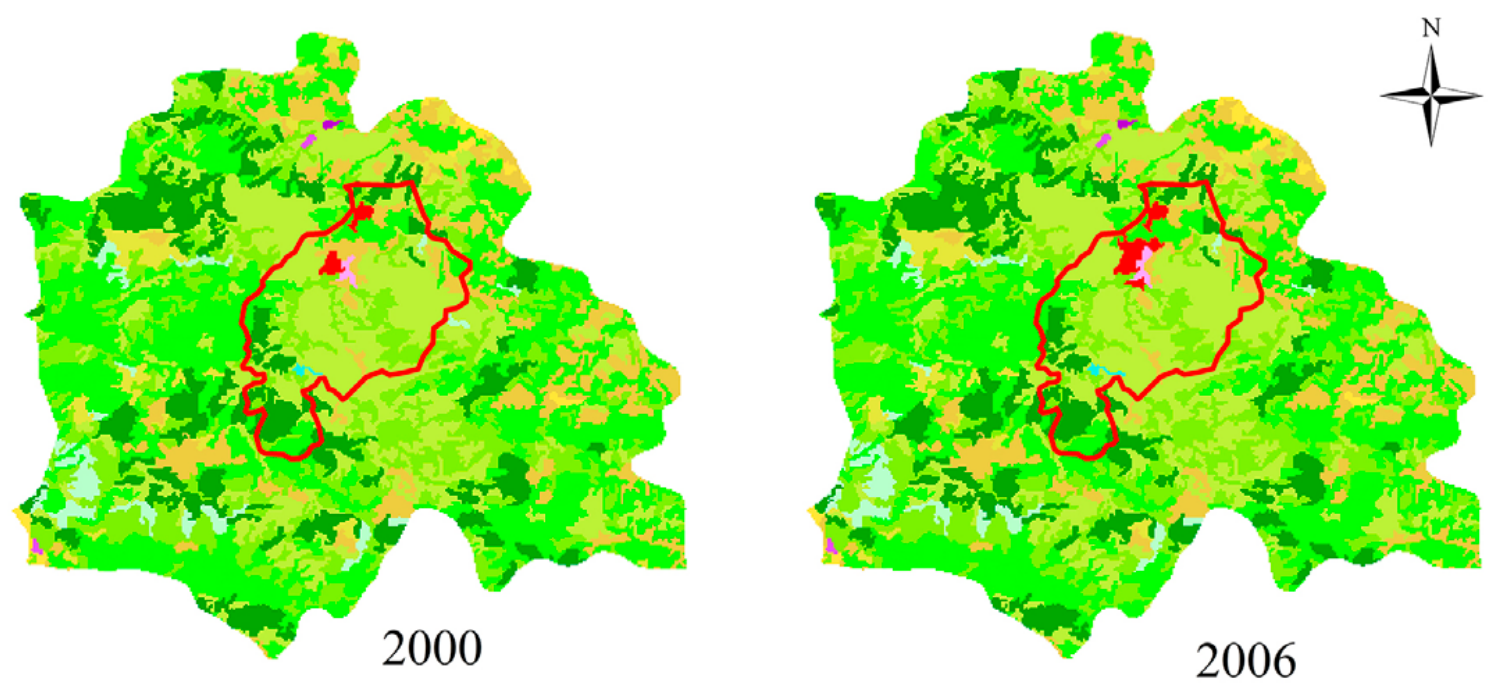

Legend

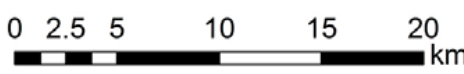

2006

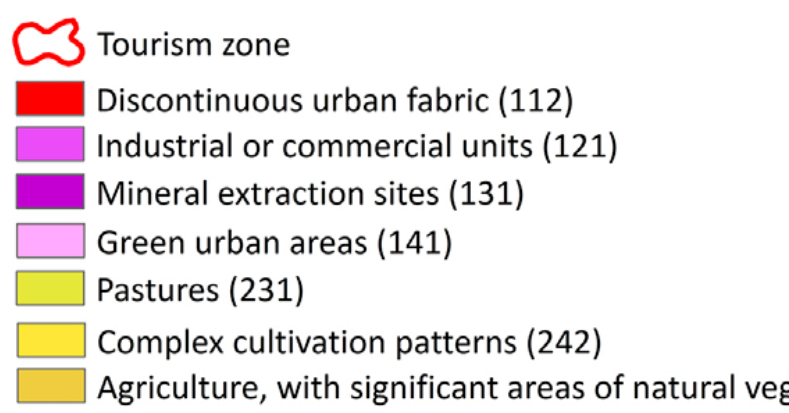
Agriculture, with significant areas of natural veg. (243)

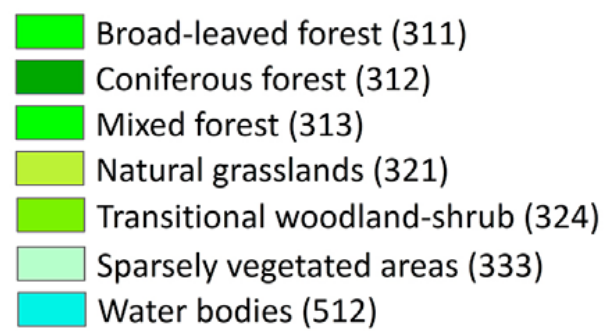

Figure 3. Third level CLC classes in Čajetina municipality in 2000 and 2006 
ated the tourism area around main developed tourism centre. This area is arbitrary as it is made as a compromise of different sources in order to be able to compare multiple time periods. Since it is influenced highly by the subjective judgment of the authors its only purpose is to quantify possible effects of main developed tourism zone on near surrounding areas. Therefore, it cannot be used to represent any official spatial or development plan.

Unfortunately, this study did not include CLC data for 2012. At the moment of analysis this product needed a technical semantic check to be finished. Particularly, for the study area there were semantic inconsistencies comparing to two previous versions of the map product.

\section{Quantification of land use}

For the purpose of this study, for analysis of land use patterns, following metrics was used: Class area (CA) and Percentage of landscape (PLAND), Number of patches (NP) and Patch Density (PD), Mean patch size (MPS) and Patch Size Standard Deviation (PSSD).

Class area (CA) is a measure of landscape composition that tells how much of the landscape is comprised of a particular patch type. CA equals the sum of the areas $(\mathrm{m} 2)$ of all patches of the corresponding patch type, divided by 10.000 (to convert to hectares); that is, total class area (McGarigal, Marks, 1995).

Percentage of landscape (PLAND) quantifies the proportional abundance of each patch type in the landscape. It is a measure of landscape composition. However, because PLAND is a relative measure, it may be a more appropriate measure of landscape composition than class area for comparing among landscapes of varying sizes. PLAND equals the sum of the areas $\left(\mathrm{m}^{2}\right)$ of all patches of the corresponding patch type, divided by total landscape area $\left(\mathrm{m}^{2}\right)$, multiplied by 100 (to convert to a percentage); in other words, PLAND equals the percentage the landscape comprised of the corresponding patch type (McGarigal, Marks, 1995).

Patch density (PD) is fundamental aspect of landscape pattern. Patch density has the same basic utility as number of patches as an index, except that it expresses number of patches on a per unit area basis that facilitates comparisons among landscapes of varying size. PD equals the number of patches of the corresponding patch type divided by total landscape area $\left(\mathrm{m}^{2}\right)$, multiplied by 10.000 and 100 (to convert to 100 hectares) (McGarigal, Marks, 1995).

Another class index based on the number of patches is Mean patch size (MPS). The size of each patch comprising a landscape mosaic is perhaps the single most important and useful piece of information contained in the landscape. The size comprised by each patch type (class) is equally important. Mean patch size equals the sum of the sizes of all land cover patches divided by the number of patches of the same type, divided by 10.000 (to convert to hectares) (McGarigal, Marks, 1995).

Patch size standard deviation (PSSD) is a measure of absolute variation as it is a function of the mean patch size and the difference in patch size among patches. Thus, although patch size standard deviation conveys information about patch size variability, it is a difficult parameter to interpret without doing so in conjunction with mean patch size because the absolute variation is dependent on mean patch size. PSSD equals size deviation of each land cover patches in own classes (McGarigal, Marks, 1995; Klaučo, et al; 2013).

\section{Results}

Outputs of the landscape quantification are numerical values that can be interpreted toward effects of development on land use changes.

The tourism area (zone) in Čajetina municipality, as shown in Table 1, occupies $13.16 \%$ of the total study area. At municipality level, 758 ha of total CA was part of change (increasing or decreasing of size), but that is just $1.18 \%$. At tourism area the level of absolute changes was 436 ha. This is $5.16 \%$ of total CA that was under some kind of change.

The biggest increase of CA was recorded in discontinuous urban fabric, green urban areas and water bodies. Those three classes are completely located within tourism area. At municipality level significant increase of CA was also recorded in complex cultivation patterns, and at tourism area level in sparsely vegetated areas.

The biggest decrease of $\mathrm{CA}$ at municipality level was recorded in pastures. However, pastures are not present in tourism area. The biggest decrease of CA in class that shares space with tourism area was recorded in land principally occupied by agriculture with significant areas of natural vegetation.

When analyzing PLAND, it is evident that most present classes at municipality level are natural grasslands, broad-leaved forest, transitional woodlandshrub, coniferous forest, mixed forest and land principally occupied by agriculture, with significant areas of natural vegetation. Other classes have ratio smaller that $3 \%$.

The same classes are also dominant in tourism area, but predominant class in whole zone is natural grassland. Almost half of tourism (46\%) area is covered by that class.

The total number of patches (NP) in municipality remained almost unchanged. It changed for $0.19 \%$ from 535 (2000) to 536 (2006). However, the largest de- 
Table 1. Class areas (CA) and Percent of landscape (PLAND)

\begin{tabular}{|c|c|c|c|c|c|c|c|c|c|c|}
\hline \multirow{3}{*}{$\begin{array}{l}\text { CLC } \\
\text { Code }\end{array}$} & \multicolumn{5}{|c|}{ Municipality } & \multicolumn{5}{|c|}{ Tourism area } \\
\hline & \multicolumn{2}{|c|}{2000} & \multicolumn{2}{|c|}{2006} & \multirow{2}{*}{$\begin{array}{c}\text { CA } \\
(2006-2000)\end{array}$} & \multicolumn{2}{|c|}{2000} & \multicolumn{2}{|c|}{2006} & \multirow{2}{*}{$\begin{array}{c}C A \\
(2006-2000)\end{array}$} \\
\hline & CA & PLAND & CA & PLAND & & CA & PLAND & CA & PLAND & \\
\hline 112 & 179 & 0.28 & 347 & 0.54 & 168.00 & 179 & 2.12 & 347 & 4.11 & 93.85 \\
\hline 121 & 54 & 0.08 & 53 & 0.08 & -1.00 & - & - & - & - & - \\
\hline 131 & 28 & 0.04 & 29 & 0.05 & 1.00 & - & - & - & - & - \\
\hline 141 & 67 & 0.10 & 85 & 0.13 & 18.00 & 67 & 0.79 & 85 & 1.01 & 26.87 \\
\hline 231 & 1485 & 2.31 & 1356 & 2.11 & -129.00 & - & - & - & - & - \\
\hline 242 & 363 & 0.57 & 401 & 0.63 & 38.00 & - & - & - & - & - \\
\hline 243 & 6099 & 9.51 & 5985 & 9.33 & -114.00 & 749 & 8.87 & 542 & 6.42 & -27.64 \\
\hline 311 & 12563 & 19.58 & 12583 & 19.61 & 20.00 & 457 & 5.41 & 457 & 5.41 & 0.00 \\
\hline 312 & 8119 & 12.66 & 8115 & 12.65 & -4.00 & 1041 & 12.33 & 1046 & 12.39 & 0.48 \\
\hline 313 & 7932 & 12.36 & 7840 & 12.22 & -92.00 & 562 & 6.66 & 564 & 6.68 & 0.36 \\
\hline 321 & 13802 & 21.51 & 13860 & 21.60 & 58.00 & 3926 & 46.51 & 3942 & 46.70 & 0.41 \\
\hline 324 & 12112 & 18.88 & 12180 & 18.99 & 68.00 & 1401 & 16.60 & 1390 & 16.47 & -0.79 \\
\hline 333 & 1316 & 2.05 & 1277 & 1.99 & -39.00 & 24 & 0.28 & 25 & 0.30 & 4.17 \\
\hline 512 & 36 & 0.06 & 44 & 0.07 & 8.00 & 36 & 0.43 & 44 & 0.52 & 22.22 \\
\hline Total & 64155 & 100.00 & 6415 & 100.00 & - & 8442 & 100.00 & 8442 & 100.00 & - \\
\hline
\end{tabular}

crease of NP was recorded in pastures. Decrease of NP was also recorded in broad-leaved forest, mixed forest and sparsely vegetated areas. In tourism area no decrease of total NP are recorded. On the other hand, the largest increase of NP occurred in discontinuous urban fabric that is completely part of tourism area. This is a consequence of spreading of this patch type that created new patch.

The average PD of all classes at municipality level (from 0.0596 to 0.0597 patches per $100 \mathrm{ha}$ ) and in tourism area (from 0.0758 to 0.0793 patches per 100 ha) stayed almost the same.

Patches with the smallest MPS in municipality are industrial or commercial units and mineral extraction sites. Patch with MPS over 1ooha is natural grasslands and forest patches (broad-leaved forest, coniferous forest and mixed forest). In tourism area the smallest patch is water body. The largest MSI in tourism zone have natural grasslands, and MSI over 1ooha have mixed forest and transitional woodland-shrub.

Table 2. Number of patches (NP) and Patch density (PD)

\begin{tabular}{|c|c|c|c|c|c|c|c|c|c|c|}
\hline \multirow{3}{*}{$\begin{array}{l}\text { CLC } \\
\text { Code }\end{array}$} & \multicolumn{5}{|c|}{ Municipality } & \multicolumn{5}{|c|}{ Tourism area } \\
\hline & \multicolumn{2}{|c|}{2000} & \multicolumn{2}{|c|}{2006} & \multirow{2}{*}{$\begin{array}{c}\text { NP } \\
(2006-2000)\end{array}$} & \multicolumn{2}{|c|}{2000} & \multicolumn{2}{|c|}{2006} & \multirow{2}{*}{$\begin{array}{c}\text { NP } \\
(2006-2000)\end{array}$} \\
\hline & NP & PD & NP & PD & & NP & PD & NP & PD & \\
\hline 112 & 2 & 0.0031 & 3 & 0.0047 & 1 & 2 & 0.0237 & 3 & 0.0355 & 1 \\
\hline 121 & 2 & 0.0031 & 2 & 0.0031 & 0 & - & - & - & - & - \\
\hline 131 & 1 & 0.0016 & 1 & 0.0016 & 0 & - & - & - & - & - \\
\hline 141 & 1 & 0.0016 & 1 & 0.0016 & 0 & 1 & 0.0118 & 1 & 0.0118 & 0 \\
\hline 231 & 19 & 0.0296 & 17 & 0.0265 & -2 & - & - & - & - & - \\
\hline 242 & 8 & 0.0125 & 11 & 0.0171 & 3 & - & - & - & - & - \\
\hline 243 & 76 & 0.1185 & 78 & 0.1216 & 2 & 8 & 0.0948 & 9 & 0.1066 & 1 \\
\hline 311 & 78 & 0.1216 & 77 & 0.1200 & -1 & 6 & 0.0711 & 6 & 0.0711 & 0 \\
\hline 312 & 51 & 0.0795 & 51 & 0.0795 & 0 & 12 & 0.1421 & 12 & 0.1421 & 0 \\
\hline 313 & 63 & 0.0982 & 62 & 0.0966 & -1 & 5 & 0.0592 & 5 & 0.0592 & 0 \\
\hline 321 & 88 & 0.1372 & 88 & 0.1372 & 0 & 15 & 0.1777 & 15 & 0.1777 & 0 \\
\hline 324 & 125 & 0.1948 & 125 & 0.1948 & 0 & 13 & 0.154 & 14 & 0.1658 & 1 \\
\hline 333 & 20 & 0.0312 & 19 & 0.0296 & -1 & 1 & 0.0118 & 1 & 0.0118 & 0 \\
\hline 512 & 1 & 0.0016 & 1 & 0.0016 & 0 & 1 & 0.0118 & 1 & 0.0118 & 0 \\
\hline
\end{tabular}


Table 3. Mean patch size (MPS) and Patch size standard deviation (PSSD)

\begin{tabular}{|c|c|c|c|c|c|c|c|c|c|c|}
\hline \multirow{3}{*}{$\begin{array}{l}\text { CLC } \\
\text { Code }\end{array}$} & \multicolumn{5}{|c|}{ Municipality } & \multicolumn{5}{|c|}{ Tourism area } \\
\hline & \multicolumn{2}{|c|}{2000} & \multicolumn{2}{|c|}{2006} & \multirow{2}{*}{$\begin{array}{c}\text { MPS } \\
(2006-2000)\end{array}$} & \multicolumn{2}{|c|}{2000} & \multicolumn{2}{|c|}{2006} & \multirow{2}{*}{$\begin{array}{c}\text { MPS } \\
(2006-2000)\end{array}$} \\
\hline & MPS & PSSD & MPS & PSSD & & MPS & PSSD & MPS & PSSD & \\
\hline 112 & 89.50 & 3.50 & 115.67 & 81.18 & 29.24 & 89.5 & 3.50 & 115.67 & 81.18 & 29.24 \\
\hline 121 & 27.00 & 1.00 & 26.50 & 1.50 & -1.85 & - & - & - & - & - \\
\hline 131 & 28.00 & 0.00 & 29.00 & 0.00 & 3.57 & - & - & - & - & - \\
\hline 141 & 67.00 & 0.00 & 85.00 & 0.00 & 26.86 & 67 & 0.00 & 85 & 0.00 & 26.86 \\
\hline 231 & 78.16 & 98.02 & 79.76 & 103.61 & 2.05 & - & - & - & - & - \\
\hline 242 & 45.37 & 46.96 & 36.45 & 53.72 & -19.66 & - & - & - & - & - \\
\hline 243 & 80.25 & 88.11 & 76.73 & 84.40 & -4.37 & 93.62 & 78.32 & 60.22 & 25.26 & -35.68 \\
\hline 311 & 161.06 & 309.42 & 163.41 & 315.77 & 1.46 & 76.17 & 89.80 & 76.17 & 88.84 & 0 \\
\hline 312 & 159.20 & 221.19 & 159.12 & 220.50 & -0.05 & 86.75 & 120.12 & 87.17 & 120.81 & 0.48 \\
\hline 313 & 125.90 & 190.94 & 126.45 & 192.42 & 0.44 & 112.4 & 67.56 & 112.8 & 68.18 & 0.35 \\
\hline 321 & 156.84 & 405.13 & 157.5 & 408.38 & 0.42 & 261.73 & 482.97 & 262.8 & 482.41 & 0.41 \\
\hline 324 & 96.90 & 146.86 & 97.44 & 146.35 & 0.56 & 107.77 & 170.76 & 99.28 & 164.56 & -7.88 \\
\hline 333 & 65.80 & 63.87 & 67.21 & 65.19 & 2.14 & 24 & 0.00 & 25 & 0.00 & 4.17 \\
\hline 512 & 36.00 & 0.00 & 44.00 & 0.00 & 22.22 & 36 & 0.00 & 44 & 0.00 & 22.22 \\
\hline
\end{tabular}

Four evident changes of MPS happened between 2000 and 2006. The largest growth of MPS was recorded in discontinuous urban fabric, green urban areas and water bodes at both levels. On the other hand the highest decrease of MPS in tourism area happened in land principally occupied by agriculture, with significant areas of natural vegetation and transitional woodland-shrub.

Patch size standard deviation (PSSD) is focused on the significance of size difference among patches in tourism area (Table 3). The value of PSSD that is closer to zero means same sizes of all patches. The concentrations of biggest size differences are present in following patches: natural grasslands, broad-leaved forest, coniferous forest, mixed forest and transitional woodland-shrub. The same group of patches have also the biggest value of PSSD in tourism area, excluding mixed forest and broad-leaved forest. The biggest change of PSSD between two periods was recorded in discontinuous urban fabric, both at municipality and tourism zone level.

\section{Conclusions and limitations}

Beside the evident influence of tourism to environment, such as consumption of area, there are also other effects. Sometimes the influence of tourism is often "hidden" and cannot be easily detected. Tourism development usually affects purpose of land use at the destination and surrounding areas. Luckily, those influences can be quantified and measured. Within this context, landscape metrics can be used as a tool for assessing effects of development on land use changes in tourism destination. The authors tested this thesis in Čajetina municipality, on the area of most prominent tourism area in Serbia - Zlatibor Mt.

In last decades the area of Zlatibor Mt. are under strong influences of development and the process of urbanization. The study of Jovanović, et al. (2015) that analysed different satellite imagery of Zlatibor Mt. with its surroundings in a certain period of time $(1985$ - 2013) showed that the surface under the forests is reduced for about $4 \%$ while the built up area has doubled. For the area of Čajetina Municipality this study shows that human influences are most evident in core of tourism zone.

The results of this research revealed that higher level of land use changes between two tested periods have occurred in the tourist zone comparing to surrounding areas. Discontinuous urban fabric, where new dwellings emerge, has the highest level of change due to the increase of the area between two tested periods. Most of that change goes to the account of decrease of land principally occupied by agriculture, with significant areas of natural vegetation.

Real landscapes contain complex spatial patterns in the distribution of resources that vary over time; quantifying these patterns and their dynamics is the purview of landscape pattern analysis. Landscape patterns can be quantified in a variety of ways depending on the type of data collected, the manner in which it is collected, and the objectives of the investigation (Urban, et al., 1987). Proposed methodology is just a framework for more detailed studies that can be implemented. One of the main limitations of proposed methodology can be scale factor. Landscape metrics 
focus on the characterization of the geometric and spatial properties of map patterns represented at a particular scale. For more detailed analysis more detail maps are necessary. That can make the whole process more complicated, more time consuming and, consequently more expensive. Moreover, landscape metrics quantify the pattern of the landscape within the designated landscape boundary only. The interpretation of these metrics requires awareness of the landscape context and the openness of the landscape relative to the phenomenon under consideration (Wiens, 1976; Kotliar, Wiens 1990). Finally, the interrelation of landscape metrics is obviously limited by temporal and classification settings of the CLC data used.

\section{References}

Atik, M., Altan, T., Artar, M. 2009. Land Use Changes in Relation to Coastal Tourism Developments in Turkish Mediterranean. Polish Journal of Environmental Studies 19,1, 21-33.

Bastian, O., Steinhardt, U. 2002. Development and Perspectives of Landscape Ecology. Kluwer Academic Publishers, Dordrecht, 498 pp.

Business (master) plan of the tourist destination of Zlatibor-Zlatar. 2007. Singidunum University, Belgrade.

Đenić, M. 1970. Zlatibor. Dimitrije Tucović, Titovo Užice, 227 pp. (In Serbian).

Dolinaj, D., Pašić, M., Stojanović, V. 2009. Theoretical and Practical Approach of Connecting the Ecotourist Offer of the Special Nature Reserve of Zasavica (Serbia) with the Tourist Offer of the Surrounding Village Settlements. Turizam 13,2, 92-101.

Dragović, R., Filipović, I., Nikolić, J. 2009. Possibility of exploitation of natural and geographic conditions of Zlatibor and Zlatar for the development of ecotourism and health tourism. Glasnik Srpskog geografskog drustva 89,1,115-128.

Feranec, J., Jaffrain, G., Soukup, T., Hazeu, G. 2010. Determining changes and flows in European landscapes 1990-2000 using CORINE land cover data. Applied Geography 30,1, 19-35.

Gustafson, E. J. 1998. Quantifying landscape spatial pattern: What is the state of the art? Ecosystems 1, 143-156.

Herold, M., Scepan, J., Clarke, K.C. 2002. The use of remote sensing and landscape metrics to describe structures and changes in urban land uses. Environment and Planning A 34,8, 1443-1458.

Heymann, Y., Steenmans, Ch., Croissille, G., Bossard, M. 1994. Corine Land Cover. Technical Guide. Office for Official Publications of the European Communities, Luxembourg, $136 \mathrm{pp}$.
Jovanović, D., Govedarica, M., Sabo, F., Bugarinović, Ž, Novović, O, Beker, T., Lauter, M. 2015. Land Cover change detection by using Remote Sensing - A Case Study of Zlatibor (Serbia), Geographica Pannonica 19,4, 162-173.

Jovanović, V., Njeguš, A. 2008. The application of GIS and its components in tourism. Yugoslav Journal of Operations Research 18,2, 261-272.

Jovanovic, V., Njegus, A. 2010. Geographical Information System and Its Application in Spatial Management. The Case of Zlatibor and Zlatar, Serbia. Journal of Environmental Protection and Ecology 7,1, 306-316.

Jovičić, A., Berić, D., Petrović, M. D., Gagić, S. 2013. The significance of the tourist destination of Zlatibor spatial planning. Glasnik Srpskog geografskog društva 93,2, 91-112.

Kareiva, P., Wennergren, U. 1995. Connecting landscape patterns to ecosystem and population processes. Nature 373, 299-302.

Klaučo, M., Gregorová, B., Stankov, U., Marković, V., Lemenkova, P. 2013. Determination of ecological significance based on geostatistical assessment: a case study from the Slovak Natura 2000 protected area. Open Geosciences 5,1, 28-42.

Klaučo, M., Gregorová, B., Stankov, U., Marković, V., Lemenkova, P. 2015. Land Planning as a Support for Sustainable Development Based on Tourism: A case Study of Slovak Rural Region. In: Handbook on Tourism and Management. 1st published. New York: Nova Science Publishers, 191-208 pp.

Klauco, M., Weis, K., Stankov, U., Marković, V., Arsenović, D. 2012. Ecological Significance of LandCover Based on Interpretation of Human-Tourism Impact. A Case from Two Different Protected Areas (Slovakia and Serbia). Carpathian Journal of Earth and Environmental Sciences 7,3, 231-246.

Kotliar, N.B., Wiens, J.A. 1990. Multiple scales of patchiness and patch structure: a hierarchical framework for the study of heterogeneity. Oikos 59, 253-260.

Marković, V., Klaučo, M., Stankov, U., Jovanović, T., Ristić, Z. 2014. Evaluation of Human Impact on the Land Cover Through Landscape Metrics: Nature Park" Šargan-Mokra Gora”(Serbia). Rocznik Ochrona Środowiska 16,1, 52-73.

McGarigal, K., Marks, B. 1995. FRAGSTATS, spatial pattern analysis program for quantifying landscape structure. - General Technical Report. USDA, Forest Service, Pacific, Northwest Research Station, Portland, $141 \mathrm{pp}$.

Minetos, D., Polyzos, S. 2009. Multivariate statistical methodologies for testing hypothesis of land-use change at the regional level. A review and evalua- 
tion. Journal of Environmental Protection and Ecology 10,3, 834-866.

O’Neill, R.V., Krummel, J. R., Gardner, R.H., Sugihara, G., Jackson, B., DeAngelis, D.L., Milne, B.T., Turner, M.G., Zygmunt, B., Christensen, S.W., Dale, V.H., Graham, R.L. 1988. Indices of landscape pattern. Landscape Ecology 1, 153-162.

Regional Chamber of Commerce Užice 2012. Available at: http://www.rpk-uzice.co.rs/en/cajetina.htm (Accessed on 10 October 2012).

Ršumović, R., Milojević, M., Lazarević, M. 1991. Zlatibor - Geographical study (Zlatibor - Geografska studija). SANU, Belgrade, 288 pp. (in Serbian).

Sallay, A., Jombach, S., Filepné Kovács, K. 2012. Landscape Changes and Function Lost Landscape Values. Applied Ecology and Environmental Research 10,2,157-172.

Seto, K.C., Fragkias, M. 2005. Quantifying spatiotemporal patterns of urban land-use change in four cities of China with time series landscape metrics. Landscape Ecology 20, 871-888.

Statistical Office of the Republic of Serbia, 2001-2015. Municipalities in Serbia; Municipalities and Regions in Serbia, several yearbooks. Belgrade.

Statistical Office of the Republic of Serbia, 2011. Municipalities in Serbia 2011. Belgrade.
Stojanović, V., Dolinaj, D., Pašić, M. 2011. The humangeographic perspective of environmental studies. Zbornik Matice srpske za drustvene nauke 134, 113-119.

The Spatial Plan of Čajetina Municipality 2010. Institute of transportation CIP, Belgrade.

Turner, M.G. 1990. Spatial and temporal analysis of landscape patterns. Landscape Ecology, 4, 21-30.

Turner, M.G., Gardner, H.R., O’Neill, V.R. 2001. Landscape Ecology in Theory and Practice: Pattern and Process. Springer, New York, 405 pp.

Turner, M.G., Gardner, R.H. 1991. Quantitative methods in landscape ecology. In: Turner, M.G., Gardner, R.H. (Eds.) The Analysis and Interpretation of Landscape Heterogeneity. Springer, New York, 3-14 pp.

Urban, D.L., O’Neill, R.V., Shugart, H.H. 1987. Landscape ecology, a hierarchical perspective can help scientists understand spatial patterns. Bioscience 37, 2, 119-127.

Wickham, J.D., Norton D.J. 1994. Mapping and analyzing landscape patterns. Landscape Ecology 9, 7-23.

Wiens, J.A. 1976. Population responses to patchy environments. Annual Review of Ecology and Systematics $7,81-120$. 